九州大学学術情報リポジトリ

Kyushu University Institutional Repository

\title{
ASEANSAT: A Feasible Model for International Satellite Collaboration Project
}

Mohamad Huzaimy Jusoh

College of Engineering, Universiti Teknologi MARA : Professor

https://doi.org/10.5109/4738545

出版情報 : Proceedings of International Exchange and Innovation Conference on Engineering \& Sciences (IEICES). 7, pp. 26-27，2021-10-21. 九州大学大学院総合理工学府 バージョン:

権利関係: 


\section{Keynote Speakers}

Mohamad Huzaimy Jusoh

Professor

College of Engineering

Universiti Teknologi MARA, Malaysia

Email: huzaimy@uitm.edu.my

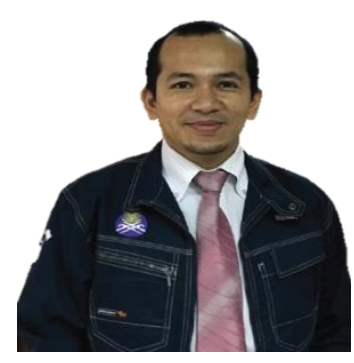

\section{Short Biography}

Dr. Mohamad Huzaimy Jusoh is a senior lecturer in School of Electrical Engineering, Universiti Teknologi MARA (UiTM) since 2007. He obtained his doctorate degree from Kyushu University, Japan, for a research in Space and Earth Electromagnetism. As an academician, he has supervised more than 20 postgraduate students, leads more than 10 research grants, and published more than 90 publications. In 2016, he led the first Malaysian team to Antarctica for a scientific expedition. He was then appointed as leader of UiTM First Nanosatellite project (UiTMSAT-1) in The Joint Global Multi-Nation Birds Satellite Programme (BIRDS-2). Through the Programme, UiTMSAT-1 was successfully launched to space in 2018. As the first Malaysia's university to launch the nanosatellite, UiTM has make a first step towards the indigenous space program where human capital development and international networking have been ascertained. With the success of UiTM Nanosatellite project, he was appointed as Visiting Professor at Kyushu Institute of Technology, Japan since 2017 until now. Dr Huzaimy has established Centre for Satellite Communication and UiTM ground station to ensure the sustainable education development, space research activities and satellite operations can be implemented hence created opportunities for many entities to involve in space technology in Malaysia and the region. Recognizing the effort and success of UiTMSAT- 1 team, recently MOSTI has awarded Dr Huzaimy, a grant under International Collaborative Fund to develop a nanosatellite locally in collaboration with Philippine and Thailand under ASEANSAT project where Dr Huzaimy is the Principal Investigator. These achievements, recognition and progress will ensure the sustainability of space-based knowledge and expertise are transferred through innovative teaching method to various levels of stakeholders including universities, schools, NGOs and public. 


\title{
ASEANSAT: A Feasible Model for International Satellite Collaboration Project
}

\begin{abstract}
Universiti Teknologi MARA (UiTM) has deployed its first nano satellite into space, UiTMSAT-1, which is the Malaysian's university nanosatellite, on 10 August 2018. It is the result of a joint collaboration project called Joint Global Multi-Nation BIRDS-2 project with Bhutan and the Philippines led by Kyushu Institute of Technology (KyuTech), Japan. This success has forged UiTM in the field of nanosatellite technology. The success of the BIRDS-2 project has inspired UiTM to lead the second nanosatellite development project, ASEANSAT, comprises students and lecturers from ASEAN countries from the Phillipine and also Thailand as technical members. This cooperative research programme is an international universities collaboration between UiTM and University of Perpetual Delta Help (UPHSD) to jointly develop a 1U Nanosatellite called ASEANSAT. The main purpose of the research programme for UiTM and UPHSD students/lecturers is to obtain practical exposure, participate in hands-on training and learn/involve in the entire process of Nanosatellite development. By this ASEANSAT Project collaboration, human capital, and expertise among UiTM and UPHSD students/lecturers in the field of space technology will be built-up. International network between universities in ASEAN countries, government agencies as well as international space agency will be established which will drive into the development of Nanosatellite technology in participating ASEAN countries. This ASEANSAT project will drive research and development of nanosatellite technology in Malaysia and ASEANSAT countries. The importance of the development of nano satellite technology in the region is undeniable, as it touches on the strengthening of various industries including agriculture, fisheries, communications, and security. In addition, this project contributes to the development of human resources and creates a knowledge-based society, as well as aiding in economic development, social progress and innovation for ASEAN and global.
\end{abstract}

